\begin{abstract}
(c) (i)
\section{The effect of the Covid-19 Pandemic on pediatric urology}

\author{
Anna Bujons Tur ${ }^{1}$, Juan Carlos Prieto ${ }^{2}$, Andrés Gómez-Fraile ${ }^{3}$, Juan Pablo Corbetta ${ }^{4}$ \\ ${ }^{1}$ Department of Urology, Division Urology Pediatric, Fundació Puigvert Barcelona, Spain; ${ }^{2}$ Division \\ Urology Pediatric, University of Texas Health Science Center, Children's Hospital of San Antonio and \\ Methodist Children's Hospital, San Antonio, TX, USA; ${ }^{3}$ Department of Pediatric Surgery, Pediatric \\ Urology Division, Hospital 12 de Octubre, Madrid, Spain; ${ }^{4}$ Department of Pediatric Urology, Hospital \\ Prof. Dr. Juan P. Garrahan, Buenos Aires, Argentina
}

\section{ABSTRACT}

Medical and surgical priorities have changed dramatically at the time of this pandemic. Scientific societies around the World have provided rapid guidance, underpinned by the best knowledge available, on the adaptation of their guidelines recommendations to the current situation. There are very limited scientific evidence especially in our subspecialty of pediatric urology. We carry out a review of the little scientific evidence based mainly on the few publications available to date and on the recommendations of the main scientific societies regarding which patients should undergo surgery, when surgery should be performed and how patient visits should be organize.

\section{ARTICLE INFO}

\section{A. Bujons}

http://orcid.org/0000-0002-3995-9329

Keywords:

Outpatients; Child; COVID-19

[Supplementary Concept];

Pandemics

Int Braz J Urol. 2020; 46 (Suppl 1): 133-44

Submitted for publication:

April 25, 2020

Accepted after revision:

April 25, 2020

Published as Ahead of Print: June 05, 2020

\section{INTRODUCTION}

Since the COVID-19 epidemic was first declared in China in December 2019 (1), the virus has spread rapidly around the World owing to its characteristics: rapid spread, high contagiousness, and mortality from viral pneumonia. Critically, hospitals in many countries have had to transform. In Europe as of April 28, there have been 880,000 cases of COVID-19, and specifically in Spain 213,000 cases have been confirmed by
Polymerase Chain Reaction (PCR) (2). We have had to convert the departments of our hospitals in an attempt to ensure that human resources and medical infrastructure were adequate to treat patients affected by COVID-19, and a key element of these efforts has been an increase in staff levels through the involvement of doctors from different specialties in the care of these patients. As our healthcare system has become increasingly saturated, most nurses have been moved to COVID-19 areas and the majority of the OR personnel have been 
moved to the ICU owing to the rise in the need for ventilated beds; these changes have entailed the added difficulty of obtaining adequate personal protective equipment (PPE). Other specialized hospitals have been declared COVID-19 free in order to allow treatment of all patients considered non-infected. Pregnant COVID-19 patients have been transferred to these centers, and all cases of pediatric disease are being treated exclusively in maternal and pediatric hospitals. The COVID-19 crisis has forced health care providers to establish priorities for the treatment of pathologies and to suspend elective surgeries, all with the aim of increasing the number of personnel, and this, too, has meant an involuntary change in our health care systems (3). The decision on which type of care should be postponed and which should continue will need to be reviewed as the pandemic situation changes.

Medical and surgical societies around the World have provided rapid guidance, underpinned by the best knowledge available, on the adaptation of their guidelines recommendations to the current situation (4). But we must also ask ourselves what strategy to follow for those COVID-19 patients who require surgical interventions, bearing in mind the very limited scientific evidence currently available, especially in our subspecialty of pediatric urology.

Here, we carry out a review of the scant scientific evidence based mainly on the few publications available to date and on the recommendations of the main scientific societies regarding which patients should undergo surgery, when surgery should be performed, how patient visits should be organized, which risks need to be addressed, which surgical techniques are safer in this pandemic, how we should protect ourselves, and what risks a child faces when undergoing an operation affected by COVID-19.

\section{SPECIAL CONSIDERATIONS IN CHILDREN PE- DIATRIC PATIENTS, COVID-19 INFECTION, AND COMORBIDITIES}

The rapid spread of coronavirus disease 2019 (COVID-19) caused by severe acute respiratory syndrome coronavirus 2 (SARS-CoV-2) has led to a global pandemic, with infection of individuals of all ages residing in almost every country in the World (5). The pediatric population appears to be affected in much smaller proportions than adults, with only $2 \%$ of cases described in patients under age 20. According to data published by the Chinese Center for Disease Control and Prevention, only $1 \%$ of cases occur in those aged between 10 and 19 years and 1\% in children under 10 years old (6).

An epidemiologic report described 731 confirmed COVID-19 cases in the pediatric population, with over $90 \%$ of patients characterized as asymptomatic or as having mild or moderate symptoms (7). In more severe cases, symptoms can include gastrointestinal symptoms and patients can progress to respiratory failure, shock, coagulation dysfunction, renal damage, septic shock, and multiorgan failure. A case of Kawasaki disease with concurrent COVID-19 infection has recently been published in the literature (8), and cutaneous manifestations of COVID-19 have also been reported in children (9).

As we know, at the moment there is no specific treatment. Symptomatic treatment is administered in mild and moderate cases, with supportive measures and/or treatment of complications in severe cases. Numerous controlled clinical trials with newly developed molecules and drugs already authorized for other indications have been launched for complicated cases, primarily within hospitals (10).

In Spain, the above-described trend continued in April: as of 3 April there were 111 confirmed cases in children under 2 years of age $(0.2 \%)$, 39 in children aged between 2 and 4 years $(0.1 \%)$, and 193 in children aged between 5 and 14 years (0.3\%). Data were extracted from $54 \%$ of the reported cases $(63,002$ cases) as of that date $(117,710$ cases) (11). Based on the currently available data, children with COVID-19 have a better prognosis than adults, with few reported severe cases, and in mild cases recovery occurs within 1-2 weeks of disease onset. Most of the confirmed cases were secondary to exposure to family contacts. However, transmission from children to adults and other children can occur, as documented in a number of pediatric cases in China. On the other hand, it has 
been reported that the elimination of the virus in respiratory secretions and feces occurs over a longer period in children with mild symptoms than in adults, a fact that represents a great challenge for infection control (12). Transmission of the virus from asymptomatic children and a carrier period of up to 21 days have also been demonstrated. These data may explain a greater number of infections. Therefore, children should participate in the usual preventive actions to contain spread of the infection, and the protection of health professionals during evaluation and examination of children with respiratory infections is crucial (11).

While most cases of COVID-19 in children are not severe, there is a population with higher risk factors for poor disease course (Table-1) (9). One of the questions frequently asked by our urological pediatric patients or parents is whether they are at higher risk of suffering from COVID-19 due to their congenital urological diseases the fact that up to now there is no scientific evidence that congenital uropathy is a risk factor for poor evolution for the development of complications in patients with SARS-COVID-2.

When a patient is admitted to our pediatric urology unit and we suspect COVID-19 due to fever or suggestive symptoms, we carry out the PCR test with a pharyngeal sample to rule it out, as well as blood tests (hemogram, coagulation, venous blood gas, biochemistry with LDH, PCR, and PCT) and chest radiography (ideally portable). The use of chest ultrasound should be considered if it is available and if trained personnel are available to perform it. A single family member or other companion authorized by the parents must remain with the patient at all times, complying with the recommended isolation measures (surgical mask, gown, and frequent hand washing). It is recommended that the companion always be the same. In patients with severe disease, measurement of CPK, troponin, BNP, fibrinogen, D-dimer, and ferritin levels is recommended, as well as the acquisition of other data on hemophagocytic lympho-histiocytosis. Need for lumbar puncture will be assessed if neurological symptoms arise. Indication for other complementary tests will be evaluated according to the circumstances in each case.

\section{SPECIAL CONSIDERATIONS IN THE SELECTION OF CARE FOR UROPEDIATRIC PATIENTS}

Scientific societies for urology, such as the European Association of Urology (EAU) and the American Urological Association (AUA) (13), have created their own information centers for COVID-19 where they can be consulted.

The American College of Surgeons has established basic principles for clinical practice during this period. They recommend minimization of exposure to the hospital environment, with the following guiding principles:

- The goal is to provide timely surgical care to children with emergent and urgent pediatric surgical issues while optimizing patient care resources (e.g., hospital and intensive care unit beds, personal protective equipment, ventilators) and preserving the health of caregivers.

- There is no substitute for sound surgical judgment.

- Surgery should be performed only if delaying the procedure is likely to prolong hospital stay, increase the likelihood of later hospital admission, or cause harm to the patient.

- Children who have failed attempts at medical management of a surgical condition should be considered for surgery to decrease the future use of resources (e.g., recurrent infections in a branchial cleft cyst following a course of antibiotics).

- Shared multidisciplinary decisions regarding surgical scheduling should be made in the context of available institutional resources that will be variable and rapidly evolving.

- Telemedicine and teleconsultation services should be used for patient and physician interaction when available. For this, the creation of local review committees for decision-making related to COVID-19 surgical triage is very important (14). 
Table 1 - Groups of children at higher risk for poor disease course (Spanish Association of Pediatrics).

\begin{tabular}{ll}
\hline Immunosuppressed child & Primary immunodeficiencies (1) \\
& Solid organ transplant and hematopoietic progenitor transplantation \\
& Treatment with chemotherapy, immunosuppressants, or biological drugs \\
& Poorly controlled HIV (detectable CV, CD4 decrease, or CD4/CD8 inversion ratio) \\
& With hemodynamic repercussions \\
Heart disease & With requirement for medical treatment \\
& Pulmonary hypertension \\
& On transplant waiting list \\
& Recent surgery or catheterization \\
& Cystic fibrosis \\
Chronic respiratory pathology & Bronchopulmonary dysplasia \\
(chronic lung diseases) & Severe asthma \\
Under tracheostomy, oxygen therapy, or home mechanical ventilation & \\
Dialysis & Sickle cell disease \\
Type 1 diabetes mellitus with poor metabolic control \\
Severe malnutrition, short bowel, epidermolysis bullosa, severe encephalopathies, \\
myopathies, inborn errors of metabolism, etc.
\end{tabular}

\section{URGENT AND ELECTIVE SURGERIES}

When the term "urgent surgery" is applied in the specialty of urology, and specifically in adult patients, one most commonly thinks of surgeries for oncological conditions or obstructive urolithiasis with risk of sepsis, which are much less frequent in children. On the other hand, within pediatric urology, one might think of testicular torsions as requiring urgent surgery, or of Wilms tumors, but these are much less frequent than the indications in adults. Most of our patients have congenital pathologies, and in our day-to-day practice we perform mostly reconstructive surgeries, although we can also treat obstructive lithiasis or pathologies involving risk of loss of kidney function. Prioritizing what is urgent or "elective" in this context may be more difficult than in adults. Due to these problems, European societies such as British Association of Pediatrics Urologist (BAPU) and the EAU/ESPU have published recommendations for pediatric urological procedures (Table-2) (4).

\section{EAU/ESPU Recommendations}

Panels were asked to provide tables with recommendations based on the level of priority, including those that the panels felt were critical drivers of outcome and would especially be impacted by the current crisis, and always based on the highest level of evidence that was possible.

LOW PRIORITY: Clinical harm (very unlikely if postponed for 6 months).

INTERMEDIATE PRIORITY: Cancel procedure but reconsider if there is an increase in capacity (postponement for more than 3 months not recommended: clinical harm possible but unlikely if the procedure is postponed for more than 3 months).

HIGH PRIORITY: The last procedure to be cancelled; prevent delay of $>6$ weeks. Clinical harm (e.g., loss of organ function) very likely if the procedure is postponed for $>6$ weeks).

EMERGENCY: Cannot be postponed more than 24 hours. Life-threatening/organ function-threatening condition. 
The BAPU also recommends that routine surgery be discontinued. Emergency surgery should be limited to category 4 or 5 , unless local capacity is good enough to allow category 3 to be considered (15).

\section{ROUTINE PREOPERATIVE PCR IN CHILDREN}

Is PCR recommended in all children before any surgery?

The EAU/ESPU guidelines recommend performing PCR for the COVID-19 test prior to any surgical intervention whenever possible (16). Nasopharyngeal swab with RT-PCR performed within $48 \mathrm{~h}$ preoperatively for the detection of $\mathrm{CO}$ VID-19 unfortunately shows a false negative rate of $30 \%-40 \%$ (17); however, it is always useful (18). If it cannot be performed or the test result is unknown, the patient is to be treated as positive and the number of personnel present in the operating room limited in order to reduce risks. Unfortunately, the literature regarding the effect of surgery on susceptibility to COVID-19 is very limited and relates only to adults. In one study, the mean age of 34 patients who underwent elective surgeries (levels 3 and 4) during the incubation period of COVID-19 was 55 years. All patients developed COVID-19 pneumonia shortly after surgery; $44.1 \%$ of the patients required admission to ICU during disease progression and 20.5\% died after admission to ICU (19).

Regional or local anesthesia should be considered whenever possible to prevent the need for mechanical ventilation, although local anesthesia is very rare in children compared with adults (11).

Risk of contagion in operating room situations

We know that certain procedures in the operating room generate aerosols (aerosol-generating procedures, AGP) and thereby increase the risk for surgical personnel if the patient is infected or in the incubation period (13). These include intubation, extubation, bronchoscopy, the introduction of chest tubes, electrocautery, and the use of ultrasonic devices. AGP should only be performed with full PPE, including an
N95 mask or a powered air-purifying respirator (PAPR) designed for the operating room. It is advisable to use suction devices as much as possible.

Laparoscopic/robotic/open surgical techniques The European Association for Endoscopic Surgery reports that there is very little scientific evidence on the relative risks of minimally invasive surgery versus conventional open surgery in the context of COVID-19. However, it recommends that the risk of viral contamination of personnel during surgery, whether open, laparoscopic, or robotic, be considered and that protective measures be used strictly to ensure the safety of operating room personnel and to maintain a functioning workforce. For minimally invasive procedures, the use of devices to filter released $\mathrm{CO} 2$ for aerosol particles should be considered (20). While insufficient data are available to recommend for or against an open approach versus a laparoscopic/robotic approach, the surgical team must choose an approach that minimizes operating time and maximizes safety for both patients and staff (21).

In the Chinese experience, 3,387 healthcare workers were infected with COVID-19 with a mortality of $0.6 \%$. In this setting, special caution is mandatory to reduce the infection among healthcare workers caring for COVID-19 patients. The EAU Robotic Urology Section (ERUS) has developed guidelines for robotic surgery during the COVID-19 emergency. In the case of nondeferrable surgery, the release of surgical smoke during laparoscopic procedures may carry small viral particles. As a consequence, any laparoscopic or robotic surgery should be performed only when necessary. It may be of particular importance to perform robotic surgery at the lowest permissible intraabdominal pressure (22).

As reported by Zheng et al. (23), ultrasonic scalpels or the electrical equipment commonly used in minimally invasive surgery can easily produce large amounts of surgical smoke, and in particular, the low-temperature aerosol from ultrasonic scalpels or scissors cannot effectively deactivate the cellular components 
Table 2 - Recommendations from the EAU/ESPU Paediatric Urology Guidelines Panel applicable during the COVID-19 pandemic.

\begin{tabular}{|c|c|c|c|c|}
\hline Priority category & Low priority & Intermediate priority & High priority & Emergency \\
\hline Definition & $\begin{array}{l}\text { Clinical harm very } \\
\text { unlikely if postponed } 6 \\
\text { months }\end{array}$ & $\begin{array}{l}\text { Clinical harm possible if } \\
\text { postponed } 3-4 \text { months but } \\
\text { unlikely }\end{array}$ & $\begin{array}{l}\text { Clinical harm very likely } \\
\text { if postponed }>6 \text { weeks. }\end{array}$ & Life-threatening situation \\
\hline $\begin{array}{l}\text { COVID } \\
\text { recommendation }\end{array}$ & $\begin{array}{l}\text { Benign scrotal and penile } \\
\text { pathology, incontinence. }\end{array}$ & $\begin{array}{l}\text { Semiurgent cases like initial } \\
\text { postoperative ultrasound after } \\
\text { upper tract surgery. }\end{array}$ & $\begin{array}{l}\text { Urgent cases in which } \\
\text { delay may cause } \\
\text { irreversible progression } \\
\text { or organ damage: } \\
\text { includes ultrasound, } \\
\text { VCUG in suspected } \\
\text { severely obstructed } \\
\text { uropathy where surgery } \\
\text { is still considered. }\end{array}$ & $\begin{array}{l}\text { Continue all care in } \\
\text { which delay is potentially } \\
\text { organ threatening or life } \\
\text { threatening. }\end{array}$ \\
\hline
\end{tabular}

\begin{tabular}{|c|c|c|c|c|}
\hline \multicolumn{5}{|c|}{ Postoperative follow -up schedule after surgery } \\
\hline Priority category & Low priority & Intermediate priority & High priority & Emergency \\
\hline Definition & $\begin{array}{l}\text { Clinical harm very } \\
\text { unlikely if postponed } 6 \\
\text { months. }\end{array}$ & $\begin{array}{l}\text { Clinical harm possible if } \\
\text { postponed } 3-4 \text { months but } \\
\text { unlikely. }\end{array}$ & $\begin{array}{l}\text { Clinical harm very likely } \\
\text { if postponed > } 6 \text { weeks. }\end{array}$ & Life-threatening situation. \\
\hline \multirow[t]{2}{*}{$\begin{array}{l}\text { COVID } \\
\text { recommendation }\end{array}$} & Follow-up by 6 months & $\begin{array}{l}\text { Follow-up before end of } 3 \\
\text { months }\end{array}$ & $\begin{array}{l}\text { Follow-up within <6 } \\
\text { weeks. }\end{array}$ & Follow-up within $<24 \mathrm{hr}$. \\
\hline & $\begin{array}{l}\text { Orchidopexy, hydrocele, } \\
\text { hypospadias, } \\
\text { circumcision, inguinal } \\
\text { hernia, buried penis, } \\
\text { urolithiasis if no } \\
\text { obstruction or infection. }\end{array}$ & $\begin{array}{l}\text { Any kind of antireflux surgery, } \\
\text { pyeloplasty, incontinence } \\
\text { surgery if bladder emptying is } \\
\text { working }\end{array}$ & $\begin{array}{l}\text { Pyeloplasty with } \\
\text { possible loss of } \\
\text { function. } \\
\text { Recurrent UTI after } \\
\text { antireflux surgery. } \\
\text { Incontinence surgery } \\
\text { with bladder-emptying } \\
\text { problems. }\end{array}$ & $\begin{array}{l}\text { Macroscopic hematuria } \\
\text { after trauma. } \\
\text { Inguinal hernia repair } \\
\text { with onset of scrotal } \\
\text { pain. Suspected } \\
\text { bowel obstruction or } \\
\text { intestinal perforation in } \\
\text { conjunction with bladder } \\
\text { augmentation. } \\
\text { Urolithiasis with signs of } \\
\text { sepsis and/or obstruction. } \\
\text { PUV with urinary } \\
\text { retention. } \\
\text { Local wound infection or } \\
\text { abscess formation after } \\
\text { any kind of surgery. } \\
\text { Febrile UTI/uroseptical } \\
\text { signs after any kind of } \\
\text { surgery. }\end{array}$ \\
\hline \multicolumn{5}{|c|}{ Surgical procedures for pediatric urology cases } \\
\hline Priority category & Low priority & Intermediate priority & High priority & Emergency \\
\hline
\end{tabular}




\begin{tabular}{|c|c|c|c|c|}
\hline Definition & $\begin{array}{l}\text { Clinical harm very } \\
\text { unlikely if postponed } 6 \\
\text { months }\end{array}$ & $\begin{array}{l}\text { Clinical harm possible if } \\
\text { postponed 3-4 months but } \\
\text { unlikely }\end{array}$ & $\begin{array}{l}\text { Clinical harm very likely } \\
\text { if postponed }>6 \text { weeks }\end{array}$ & Life-threatening situation \\
\hline \multirow[t]{2}{*}{$\begin{array}{l}\text { COVID } \\
\text { recommendation }\end{array}$} & Defer by 6 months & $\begin{array}{l}\text { Treat before end of } 3 \text { months } \\
\text { Perform surgery that is } \\
\text { semiurgent. }\end{array}$ & $\begin{array}{l}\text { Treat within }<6 \text { weeks } \\
\text { Perform surgery } \\
\text { for urgent cases in } \\
\text { which delay will cause } \\
\text { irreversible progression } \\
\text { of disease or organ } \\
\text { damage. }\end{array}$ & $\begin{array}{l}\text { Treat within }<24 \mathrm{hr} \text {. } \\
\text { Perform surgery in cases } \\
\text { of organ-threatening or } \\
\text { life-threatening disease. }\end{array}$ \\
\hline & $\begin{array}{l}\text { - Benign scrotal } \\
\text { and penile surgery } \\
\text { (orchidopexy, } \\
\text { hydrocele, inguinal } \\
\text { hernia, circumcision). } \\
\text { - Functional surgery } \\
\text { (incontinence surgery, } \\
\text { meatotomy, botulinum } \\
\text { toxin injections). } \\
\text { - Genital reconstructive } \\
\text { surgery (hypospadias, } \\
\text { buried penis, other } \\
\text { genital abnormalities). } \\
\text { - Benign (hemi) } \\
\text { nephrectomy. } \\
\text { - Bladder augmentation, } \\
\text { catheterizable stoma, } \\
\text { appendicocecostomy } \\
\text { due to the high and } \\
\text { prolonged impact on } \\
\text { patients and resources. } \\
\text { - Bladder exstrophy } \\
\text { correction depending } \\
\text { on age and local } \\
\text { situation. }\end{array}$ & $\begin{array}{l}\text { - Surgery for VUR (open } \\
\text { reimplant and bulk injection). } \\
\text { - Pyeloplasty if no loss of } \\
\text { function. } \\
\text { - Urolithiasis if no infection or } \\
\text { obstruction. } \\
\text { - Botulinum toxin injections for } \\
\text { neurogenic bladder only in } \\
\text { selected cases. }\end{array}$ & $\begin{array}{l}\text { - Pyeloplasty in UPJ } \\
\text { obstruction with } \\
\text { progressive loss of } \\
\text { function or severe } \\
\text { symptoms (consider } \\
\text { drainage with JJ of } \\
\text { nephrostomy). } \\
\text { - PUV. } \\
\text { - POM with } \\
\text { progressive loss of } \\
\text { function. } \\
\text { - Urolithiasis with } \\
\text { recurrent infections. }\end{array}$ & $\begin{array}{l}\text { - Urosepsis with } \\
\text { obstruction (urolithiasis, } \\
\text { ureterocele with } \\
\text { obstruction or POM). } \\
\text { - Trauma with } \\
\text { hemodynamic instability } \\
\text { or urinoma formation. } \\
\text { - PUV if urethral or } \\
\text { suprapubic catheter } \\
\text { cannot be placed. } \\
\text { - Oncology (Wilms, } \\
\text { malignant testicular/ } \\
\text { paratesticular tumors, } \\
\text { RMS of bladder and } \\
\text { prostate, resection } \\
\text { may be considered } \\
\text { depending on local } \\
\text { situation and condition } \\
\text { of child). } \\
\text { - Acute ischemia } \\
\text { (testicular torsion - in } \\
\text { neonates not exploring } \\
\text { is an option due to low } \\
\text { chance of salvaging } \\
\text { testis, very low risk } \\
\text { of metachronous } \\
\text { contralateral torsion, and } \\
\text { increased vulnerability } \\
\text { of these patients). } \\
\text { - Paraphimosis. }\end{array}$ \\
\hline
\end{tabular}

- While most children themselves may not be severely ill with COVID-19, this pandemic will impact pediatric urological care. Careful decisions must be made on what care requires postponement and what care is essential to be continued.

- Depending on the resources and capacity we recommend to only treat high-priority and emergency cases surgically during the COVID-19 pandemic.

- Consider treating intermediate-priority patients if capacity is available, but not during the COVID-19 surge.

- It is important to note that postponing surgery in patients with obstructive uropathy (UPJ, UVJ obstruction, PUV, neurogenic bladder) may lead to loss of renal function and the decision to postpone may be revised depending on the duration of the local situation as well as the severity of the obstruction in the individual case. Temporary drainage methods may be considered to bridge definitive surgery.

- Undoubtedly there will be cases of congenital abnormalities where the optimal surgical time point will be surpassed, such as hypospadias and cryptorchidism. These children may be at risk for suboptimal outcome or increased psychological burden due to delayed surgery and should be prioritized in the long waiting list.

Abbreviations: $\mathbf{P U V}=$ posterior urethral valves; $\mathbf{P O M}$ = primary obstructive megaureter; $\mathbf{U P J}=$ ureteropelvic junction; $\mathbf{V C U G}=$ voiding cystourethrogram; $\mathbf{V U R}$ = vesicoureteral reflux; $\mathbf{U V J}=$ ureterovesical junction; and $\mathbf{U T I}=$ urinary tract infection. 
of the virus in patients. These authors concluded that the particle concentration of the smoke in laparoscopic surgery is significantly higher than that in traditional open surgery $(23,24)$. Thus, it is recommended that lower electrocautery power settings be used as much as possible.

It is mandatory to confirm the complete and correct deflation of the pneumoperitoneum at the end of the procedure. In fact, due to the low gas mobility in the pneumoperitoneum, the aerosol formed during the operation tends to concentrate in the abdominal cavity. Sudden release of trocar valves, non-airtight exchange of instruments, or even small abdominal extraction incisions can potentially expose the health care team to the pneumoperitoneum aerosol. Therefore, $\mathrm{CO} 2$ should be aspirated as much as possible before removing trocars. In order to minimize the use of the operating room and optimize the use of surgical resources, procedures must be performed by experienced surgeons (20).

\section{Endoscopic procedures}

Only one report in the literature has demonstrated the presence of SARS-COV-2 in urine specimens, in $6.9 \%$ of patients, and there is no available evidence on urine transmission (26). It is recommended that endoscopic procedures and urethral catheterization be performed with caution and that surgeons should be completely protected against infection if the patient has suspected or confirmed COVID-19.

\section{OUTPATIENTS AND TELEMEDICINE}

To date, no specific treatment is available for COVID-19 infection and it is generally accepted that social distancing is the main and perhaps the only measure to prevent or contain the spread of infection so that the number of critical cases does not dramatically exceed the resources of a health system at risk of collapse. Reduction in outpatient clinic visits during va- rious stages of severity of the COVID-19 pandemic is recommended. Pediatric urology telemedicine can lead to fewer patient contacts, lower infection rates among staff, and continuation of pediatric urological care by quarantined urologists. However, the proportion of patients eligible for telemedicine, their wish to use telemedicine, and their demographic risk profile for acquiring a severe pandemic infection are unknown. The ESPU has provided guidance on the reduction of outpatient clinic visits during the various stages of severity of the COVID-19 pandemic:

- Stage 1: Start to reduce outpatient cases such as benign scrotal and penile pathology as well as incontinence.

- Stage 2: See only cases that are at least semi urgent, such as those requiring initial postoperative ultrasound after upper tract reconstruction. Consider postponing prolonged (postoperative) follow-up in stable patients.

- Stage 3: Continue care for urgent cases in which delay may cause irreversible progression of disease or organ damage. This includes ultrasound and voiding cystography in suspected severely obstructive uropathy in which surgery is still considered.

- Stage 4: Continue all care for cases in which a delay of care is potentially organ-threatening or life-threatening.

In the case of postoperative follow-up of patients with genitourinary pathologies, it is advisable to carry out the follow-up by sending photographic documentation in compliance with the General Data Protection Regulation (GDPR). If the visit has to be in person, the patient should be accompanied by a single caregiver (14). A distance of $2 \mathrm{~m}$ should be maintained between patients. Every child with suspected 
respiratory infection should wear a mask. Children under one year of age must be kept in their strollers and in baby seats or restraint systems and away from other patients. In pediatric waiting rooms, there will be no materials such as toys, books, or other objects that children can share and that cannot guarantee that recommended material hygiene and cleanliness standards are met, in addition to evidence of transmission before the manifestation of symptoms. If there are COVID-19 symptoms, the child or caregiver has tested positive for COVID-19, or they are in quarantine, they should be seen in a COVID-dedicated area of the hospital without interaction with other patients (8).

\section{TRAINING PROGRAMS}

All interhospital staff movements with residents training in other hospitals and all undergraduate clinical rounds have been canceled. All training programs for residents as well as fellowship programs in pediatric urology in Spain have been affected. Many residents have had to become so-called front-line doctors caring for patients affected by COVID-19. It is recommended that all procedures are performed by experienced urologists confident in the procedure. Procedures should be performed with the minimum number of staff members, who should also be fully trained and experienced. Furthermore, no external observers (i.e., fellows or students) should be present during procedures until the pandemic has been controlled, which we hope will be in the approaching period (22). Currently, training meetings held between companies or for the same department are scheduled via telematics.

\section{INCREASING SURGICAL ACTIVITY AFTER THE PANDEMIC IS OVER}

There is no existing knowledge on the adverse impacts of loss of surgical capacity on patients' surgical condition and associated he- alth or on prognosis. A new model will have to be established after the pandemic based on the length of the surgical waiting list.

\section{WHAT ABOUT LATIN AMERICA? WHAT HAVE THEY LEARNED FROM EUROPE'S EXPERIENCE?}

Countries in Latin America are following the programs applied in Europe because the European countries have more experience with COVID-19. In preparation for potential surges in cases of COVID-19, most governments have chosen to create new healthcare facilities and have emphasized the need for careful planning around elective procedures, taking into account multiple considerations such as adequacy of supplies of PPE and other essential equipment, testing capacity, sanitation protocols, and workforce availability. Hospitals need to maintain adequate staffing levels to cover a potential surge in COVID-19 cases and should have enough beds, PPE, ventilators, and trained staff to allow these surgeries to take place without resorting to a crisis standard of care.

Elective surgeries were initially suspended to preserve hospital bed capacity and PPE. When the data indicate a better position regarding hospital capacity, and provided individual institutions can accommodate their internal demand for PPE, it may be time to start performing some of these procedures again.

As in many countries, training programs have continued through societies, webinars, and virtual masterclasses.

Across Latin America, and indeed in all developing countries facing the COVID-19 pandemic, there are many unanswered key questions relating to impacts on the economy, levels of poverty, social and psychological problems, crime post quarantine, etc. No nation is prepared to face this crisis, but in developing countries the problem is even worse because they are all constantly in a state of crisis. In this context the post-COVID-19 era represents a huge challenge. 


\section{CONCLUSIONS}

The COVID-19 virus has been impacting dramatically on the normal life of the departments. Because of the necessity to adopt strategies to contain the diffusion, all surgical departments have to be restricted. Perform surgery only in cases of organ-threatening or life-threatening disease. Suggested reduction in outpatient clinic visits during various stages of severity of the COVID-19 pandemic.

\section{SUMMARY OF RECOMMENDATIONS}

- Consider treating only high-priority and emergency cases surgically during the COVID pandemic.

- Consider treating intermediate-priority patients if capacity is available but not during the COVID surge.

- Non-surgical management should be considered, to begin with, including medical treatment (e.g. antibiotics for vesico-ureteral reflux associated urinary tract infections), endovascular embolization (e.g. for bleeding renal traumas), or urinary tract diversion.

- Perform PCR for the COVID-19 test prior to any surgical intervention whenever possible.

- Follow the local recommendations for personal protective equipment (PPE).

- Avoid or reduce the use of monopolar electrosurgery, ultrasonic dissectors, and advanced bipolar devices, as these can lead to particle aerosolization.

- All minimally invasive procedures should preferably be performed by experienced surgeons.
- It is recommended that electrocautery power setting be lowered as much as possible in order to reduce the surgical smoke production, especially in laparoscopic surgery. During access, electrocautery should be provided with automatic suction system.

- Reduction in outpatient clinic visits during various stages of severity of the COVID-19 pandemic is recommended

- Multidisciplinary team meetings are recommended to offer the optimum therapeutics.

- Regional or local anesthesia should be considered whenever possible to prevent the need for mechanical ventilation.

\section{ABBREVIATIONS}

PCR = Polymerase Chain Reaction

BAPU $=$ British Association of Pediatrics Urologist

PPE $=$ Personal Protective Equipment

\section{CONFLICT OF INTEREST}

None declared.

\section{REFERENCES}

1. Zhu N, Zhang D, Wang W, Li X, Yang B, Song J, et al. A Novel Coronavirus from Patients with Pneumonia in China, 2019 N Engl J Med. 2020; 382:727-33.

2. [No Authors]. Información CORONAVIRUS. Gobierno de España 2020. [Internet]. Available at. <www.mscbs.gob.es>

3. Ficarra V, Novara G, Abrate A, Bartoletti R, Crestani A, De Nunzio $C$, et al. Urology practice during COVID-19 pandemic. Minerva Urol Nefrol. 2020. Epub ahead of print. 
4. Ribal MJ, Cornford P, Briganti A, Knoll T, Gravas S, Babjuk M, et al. EAU Guidelines Office Rapid Reaction Group: An organisation-wide collaborative effort to adapt the EAU guidelines recommendations to the COVID-19 era. Available at. < https://www.europeanurology.com/article/ S0302-2838(20)30324-9/fulltext>

5. Li Q, Guan X, Wu P, Wang X, Zhou L, Tong Y, et al. Early Transmission Dynamics in Wuhan, China, of Novel Coronavirus-Infected Pneumonia. N Engl J Med. 2020; 382:1199-207.

6. Chinese Center for Disease Control and Prevention(China CDC). Covid 19 Prevention and Control. [Internet]. Availalbe at. <http://www.chinacdc.cn/en/>. (accessed may 05, 2020).

7. Chen ZM, Fu JF, Shu Q, Chen YH, Hua CZ, Li FB, et al. Diagnosis and treatment recommendations for pediatric respiratory infection caused by the 2019 novel coronavirus. World J Pediatr. 2020: 1-7.

8. Jones VG, Mills M, Suarez D, Hogan CA, Yeh D, Segal JB, et al. COVID-19 and Kawasaki Disease: Novel Virus and Novel Case. Hosp Pediatr. 2020; 10:537-40.

9. Mahil SK, Yiu ZZN, Mason KJ, Dand N, Coker B, Wall D, et al. Global reporting of cases of COVID-19 in psoriasis and atopic dermatitis: an opportunity to inform care during a pandemic. Br J Dermatol. 2020. Epub ahead of print.

10. Shen K, Yang Y, Wang T, Zhao D, Jiang $Y$, Jin R, et al. Diagnosis, treatment, and prevention of 2019 novel coronavirus infection in children: experts' consensus statement. World J Pediatr. 2020: 1-9.

11. Calvo C, López-Hortelano MG, Vicente JCC, Martínez JLV; Grupo de trabajo de la Asociación Española de Pediatría para el brote de infección por Coronavirus, colaboradores con el Ministerio de Sanidad. [Recommendations on the clinical management of the COVID-19 infection by the «new coronavirus» SARS-CoV2. Spanish Paediatric Association working group]. An Pediatr (Barc). 2020;92:241.e1-241. e11. Spanish

12. Yeo $C$, Kaushal $S$, Yeo D. Enteric involvement of coronaviruses: is faecal-oral transmission of SARS-CoV-2 possible? Lancet Gastroenterol Hepatol. 2020; 5:335-37.

13. American Urological Association. Coronavirus Disease 2019. AUA Information Center. [Internet]. Available at. <https:// www.auanet.org/covid-19-info-center/covid-19-info-center>.
14. [No Authors]. American College of Surgeons. [Internet]. Available at. <https://www.facs.org/>.

15. Promoting excellence in Paediatric Urology. BAPU The British Associatiion of Paediatric urologists. [Internet]. Available at. www.bapu.org.uk (accessed April, 04, 2020)

16. Quaedackers JSLT, Stein R, Bhatt N, Dogan HS, Hoen L, Nijman RJM, et al. Clinical and surgical consequences of the COVID-19 pandemic for patients with pediatric urological problems: Statement of the EAU guidelines panel for paediatric urology, 2020. J Pediatr Urol. 2020: S1477-5131;30105-4.

17. Leboulanger N, Sagardoy T, Akkari M, Ayari-Khalfallah S, Celerier C, Fayoux P, et al. COVID-19 and ENT Pediatric otolaryngology during the COVID-19 pandemic. Guidelines of the French Association of Pediatric Otorhinolaryngology (AFOP) and French Society of Otorhinolaryngology (SFORL). Eur Ann Otorhinolaryngol Head Neck Dis. 2020; 137:177-81.

18. Brindle ME, Gawande A. Managing COVID-19 in Surgical Systems. Ann Surg. 2020. Epub ahead of print.

19. Lei S, Jiang F, Su W, Chen C, Chen J, Mei W, et al. Clinical characteristics and outcomes of patients undergoing surgeries during the incubation period of COVID-19 infection. Version 2. EClinicalMedicine. 2020; 21:100331.

20. COVID-19 Information for Paediatric Surgeons. British Association of Paediatric Surgeons. [Internet]. Available at. <www.baps.org.uk/professionals/covid-19information-for-paediatric-surgeons/>. (Last updated, June 02, 2020).

21. $\mathrm{Li} \mathrm{Cl}$, Pai JY, Chen $\mathrm{CH}$. Characterization of smoke generated during the use of surgical knife in laparotomy surgeries. J Air Waste Manag Assoc. 2020; 70:324-32.

22. Zheng MH, Boni L, Fingerhut A. Minimally Invasive Surgery and the Novel Coronavirus Outbreak: Lessons Learned in China and Italy. Ann Surg. 2020. Epub ahead of print.

23. Min Hua Zheng 1, Luigi Boni 2, Abe Fingerhut. Minimally Invasive Surgery and the Novel Coronavirus Outbreak: Lessons Learned in China and Italy. Ann Surg 2020. Epub ahead of print.

24. Luciani LG, Mattevi D, Cai T, Giusti G, Proietti S, Malossini G. Teleurology in the Time of Covid-19 Pandemic: Here to Stay? Urology. 2020; 140:4-6. 
25. Boehm K, Ziewers S, Brandt MP, Sparwasser P, Haack $\mathrm{M}$, Willems $\mathrm{F}$, et al. Telemedicine Online Visits in Urology During the COVID-19 Pandemic-Potential, Risk Factors, and Patients' Perspective. Eur Urol. 2020: S0302-2838;30323-7.

26. Ohannessian R, Duong TA, Odone A. Global Telemedicine Implementation and Integration Within Health Systems to Fight the COVID-19 Pandemic: A Call to Action. JMIR Public Health Surveill. 2020; 6:e18810.
Correspondence address:

Anna Bujons Tur MD, PhD Department of Urology, Division Urology Pediatric, Fundació Puigvert Barcelona, Spain E-mail: abujons@fundacio-puigvert.es 